\title{
Under the radar: How firms manage competitive uncertainty by appointing friends of other chief executive officers to their boards*
}

\author{
James D. Westphal $^{1}$ । David H. Zhu ${ }^{2}$
}

\author{
${ }^{1}$ Harvey C. Fruehauf Professor of Business \\ Administration, Professor of Strategy, Ross School \\ of Business, University of Michigan, Ann Arbor, \\ Michigan \\ ${ }^{2}$ Associate Professor in Management and \\ Entrepreneurship, Arizona State University and \\ Fudan University, Tempe, Arizona

\section{Correspondence} \\ James D. Westphal, Harvey C. Fruehauf Professor \\ of Business Administration, Professor of Strategy, \\ Ross School of Business, University of Michigan, \\ 701 Tappan Street, Ann Arbor, MI 48104. \\ Email: westjd@umich.edu \\ Funding information \\ National Natural Science Foundation of China, \\ Grant/Award Number: 71628202
}

Research Summary: In this study, we reveal a previously unstudied type of board tie that may help firms manage competitive uncertainty. While firms face regulatory barriers to the use of board interlock ties as a strategy for reducing competition, we suggest that firms can circumvent these barriers by appointing the friends of competitors' chief executive officers (CEOs) to their boards. Our theoretical framework addresses the antecedents, maintenance, and performance consequences of such "boardfriendship ties" to rivals. Our theory explains (a) why firms form and maintain board-friendship ties, where maintenance involves the reconstitution of broken ties and (b) how firms form and maintain these ties, by revealing the role of search firms in identifying the friends of rivals' CEOs. Empirical analyses of large-sample, longitudinal survey and archival data provide substantial support for our theory.

Managerial Summary: Firms can and do reduce competition and increase performance by appointing the friends of competitors' CEOs to their boards, and search firms (headhunters) play a key role in forming and maintaining these "board-friendship" ties to competitors. While board interlock ties between close competitors are illegal and direct friendship ties between CEOs of competitors are relatively rare, board-friendship ties are common, and yet largely unknown to antitrust regulators and external stakeholders.

\section{KEYWORDS}

boards, CEOs, competition, consultants, social networks

\footnotetext{
*Authors are listed alphabetically. We are grateful to Craig Crossland and two anonymous SMJ reviewers for valuable comments on earlier versions of this manuscript. The second author received financial support from the National Natural Science Foundation of China (project \# 71628202) and completed major parts of the project during his sabbatical at Fudan University.
} 
Board ties in the form of interlocking directorates are created when directors of one company serve on the board of another. Such ties have received much attention from management scholars and policymakers. Scholars have long argued that board ties provide a potential mechanism by which top executives can coordinate firm decisions and reduce competition (Baker \& Faulkner, 1993; Burt, 1983; Mizruchi, 1996; Palmer, Singh, \& Friedland, 1986; Pfeffer \& Salancik, 1978). However, concern about board ties among academics and policymakers has declined in recent years for several reasons. First, for many years, the Clayton Act has prohibited interlocking directorates among firms that compete in the same industry, if combining these firms would violate antitrust laws. This has created a widespread perception that directors no longer play a significant role in interfirm collusion (BuchHansen, 2014). Although interlocks between competitors do exist (in possible violation of the Clayton Act), they have never been very common, and there is little empirical evidence that they have a significant influence on firm performance (Hillman, Withers, \& Collins, 2009; Mizruchi, 1996). Second, empirical evidence indicates that board interlock ties are seldom reconstituted following the accidental loss of such ties; scholars have interpreted these findings as suggesting that board ties are not created for strategic purposes (Palmer, 1983; see review by Mizruchi, 1996; Westphal, Boivie, \& Chng, 2006). In addition, it has become increasingly impractical to form and maintain board interlock ties in which the chief executive officer (CEO) of one firm serves on another firm's board. Shareholders have pressured top executives to serve on a very limited number of boards due to concerns that "over-boarded" executives may not be able to manage their own firms properly or fulfill their duties as directors (Harris \& Shimizu, 2004). These factors are generally perceived to have significantly constrained the use of board ties as a strategy for managing competitive uncertainty.

In the present study, we challenge the widespread assumption that board ties no longer help firms reduce competition. We suggest that firms are able to manage competitive uncertainty by creating a specific kind of board tie that circumvents regulation and the other constraints on interlock ties described above. In particular, we contend that relatively high competitive uncertainty in an industry will encourage firms to appoint the friends of rivals' CEOs to their boards to facilitate interfirm coordination, creating board-friendship ties to rivals. We develop an original theoretical framework that addresses the antecedents, maintenance, and consequences of board-friendship ties. The first component of our framework explains why firms form and maintain these ties, where maintenance involves the reconstitution of broken ties. The second component of our framework addresses how firms form and maintain board-friendship ties. In particular, we explain the key role of executive search firms in identifying the friends of rivals' CEOs. Our theoretical argument suggests that search firms' expertise in eliciting sensitive information about external candidates for leadership positions makes them vital intermediaries in forming and maintaining these ties. The third component of our framework addresses the consequences of board-friendship ties for firm performance. Using large-scale, longitudinal survey data combined with archival data, we test our hypotheses on a large sample of U.S. firms, and find substantial support for our predictions.

This study contributes to the literature on boards of directors and corporate governance by identifying an unregulated type of board tie that has the potential to reduce rivalry, and explaining the mechanisms that underlie their formation, maintenance, and performance consequences. Although there is a widespread belief among researchers and policymakers that board ties among rivals are rare and do not facilitate collusion (see review by Mizruchi, 1996), our study explains how firms may reduce competition by appointing the friends of rivals' CEOs to their boards, leading to better financial performance. Prior research suggests that friendship ties among CEOs of competing firms can facilitate collusion (Westphal et al., 2006). Yet, evidence shows that friendship ties among CEOs of competing firms are increasingly rare (Bruynseels \& Cardinaels, 2014; Park \& Westphal, 2013). 
The sociological and social psychological literature on friendship indicates that genuine friendship ties normally require considerable time, effort, and attention to develop and maintain (Page-Gould, Mendoza-Denton, \& Tropp, 2008; Swart, Hewstone, Christ, \& Voci, 2011). In the present study, we explain how firms avoid these problems by appointing the friends of competitors' CEOs to the board, leveraging friendship ties that already exist. Our theory explains why appointing directors with friendship ties to competitors can facilitate interfirm communication that reduces rivalry. Thus, our study makes an important contribution to the corporate governance and strategic management literatures by explaining how corporate directors can facilitate interfirm collusion. The findings also have important public policy implications. In revealing how firms circumvent regulation by creating board ties to the friends of rivals' CEOs, our study uncovers a widely used type of board tie that calls for attention from antitrust regulators, as well as corporate governance scholars.

Our theory regarding the role of search firms in forming and maintaining board-friendship ties makes additional contributions to the corporate governance literature. Scholars have devoted very little systematic attention to understanding the role of consultants in the various processes of corporate governance, including director selection. There is also little systematic research into how consultants may reduce competition or help firms circumvent regulation. Our theory explains why search consultants play a vital role in identifying director candidates who are friends of competitors' CEOs. By explaining how board-friendship ties may facilitate collusive behavior, and then describing how search firms broker the formation and maintenance of these ties, our study ultimately suggests how consultants mediate the director selection process in ways that circumvent regulation of board ties and could facilitate collusion. Moreover, in revealing how consultants broker interfirm ties that would be viewed as illegitimate or illicit by some corporate stakeholders (e.g., customers), our study also contributes to the social network literature. While the role of third parties in brokering illicit or illegitimate ties has been identified as an important research topic in the network literature (Bonacich, 1973), very little theory or research has revealed such a role for third-party actors in business organizations.

\section{1 | THEORY AND HYPOTHESES}

\section{1 | Reducing competition through board-friendship ties to rivals' CEOs}

In this section, we explain why firms form board-friendship ties to rivals, and why they tend to rebuild such ties when broken. We suggest that board-friendship ties to competitors may help firms manage competitive uncertainty by facilitating interfirm cooperation that reduces the likelihood of destructive competition between firms, while also providing a source of competitive advantage relative to firms that lack such ties.

We begin by explaining why board-friendship ties have the potential to facilitate interfirm cooperation. First, an outside director who is a friend of a rival's CEO is in a position to help assure the rival of the firm's cooperation. Research on boards suggests that outside directors are increasingly involved with firms' major strategic decisions, and hence are well exposed to firms' strategic plans (Finkelstein, Hambrick, \& Cannella, 2009; Westphal \& Zajac, 2013). An outside director who is a friend of a rival's CEO is thus able to inform the rival's CEO about the firm's future plans because of the director's role in overseeing these decisions. The friendship between the director and the rival's CEO further renders the CEO more willing to trust information from the director about the firm's plans for interfirm cooperation. Research on friendship suggests that it typically implies trust and certain social obligations to care for each other's welfare (Krackhardt, 1992; Segal, 1979), including in 
the context of CEO-director relations (Westphal, 1999). The rival's CEO is thus likely to trust that the director friend will provide accurate information about the firm's plans and facilitate interfirm cooperation. In addition, the rival's CEO can expect that the director friend will ensure cooperation from the firm because of the director's formal authority in supervising the firm's decisions. In contrast, a friend of a rival's CEO who is not a director on the firm's board would not have the same access to information about the firm's future strategic plans or routinely receive updates about the implementation of these plans; an outside director of the firm who is not a friend of a rival's CEO may not be trusted by the CEO, and hence fail to convince the rival's CEO to cooperate with the firm.

At the same time, an outside director who is a friend of a rival's CEO can help assure the firm of the rival's cooperation. Research on CEO-board relations suggests that CEOs typically consider a large proportion of their companies' directors as friends or as supporters of their leadership (Lorsch \& MacIver, 1989; Westphal, 1999). Directors who appointed the CEO tend to support the CEO's leadership from the beginning of their relationship (Khurana, 2002), and directors who were appointed under the CEO's influence tend to feel socially obligated to return the CEO's favor by supporting the CEO's leadership in subsequent interactions (Boeker, 1992; Wade, O'Reilly, \& Chandratat, 1990; Westphal, 1999; Westphal \& Bednar, 2005). Moreover, a director who helps a competitor at the firm's expense may experience "social distancing" from fellow directors, as well as a significant loss in their social capital and reputation within the broader director labor market (Westphal \& Khanna, 2003). Westphal and colleagues have shown that directors who violate normative expectations on a particular board not only tend to experience social distancing on that board, but also on other boards where they serve as director, and they are much less likely to receive future board appointments (Westphal \& Khanna, 2003; Westphal \& Stern, 2007). ${ }^{1}$ This research indicates that social distancing is very effective at deterring directors from violating normative expectations on the boards where they serve.

In addition, outside directors who are friends of competitors' CEOs can be expected to comply with the confidentiality policy of the firm (i.e., they would face litigation risk by sharing sensitive information with CEOs of competitors without the firm's consent). Thus, an outside director who is a friend of a rival CEO has both intrinsic and extrinsic motives not to benefit a rival at the focal CEO's expense, and is therefore likely to be trusted by the focal CEO to facilitate interfirm cooperation in a fair manner. The focal CEO's trust in a director who is a friend of a rival's CEO can increase the CEO's willingness to make policy decisions that assume cooperation by the director's friend (i.e., a rival's CEO) and to trust that information provided to the director will not be exploited by the rival at the focal firm's expense. In addition, the friendship between the director and a rival's CEO implies that the rival's CEO has social obligations to care for the director's welfare (Krackhardt, 1992; Segal, 1979; Westphal, 1999), helping the director gain access to accurate and specific information about the rival's strategic plans.

Because both the focal CEO and the rival's CEO can trust the director, the director can facilitate the mutual exchange of sensitive information between the two firms. This increases the likelihood of successful collusion, and in particular may reduce the misinterpretation of policy signals that could lead to destructive competition. Research on interfirm rivalry suggests that misinterpreting policy signals is a major reason for breakdowns in cooperation (Utton, 2011). For example, in deciding whether to expand production capacities, there is the risk that two firms may both try to preempt one

\footnotetext{
${ }^{1}$ These relationships held for directors who had average levels of status in the corporate elite (Westphal \& Khanna, 2003), and are especially strong for directors with relatively low status; as discussed below, on average directors who form board-friendship ties tend to rank relatively low in comparison to other directors on at least some indicators of status in the corporate elite, including prestige of the director's primary employer and educational background.
} 
another. Without effective communications, either or both firms may misread the other's intentions and move to expand capacities, leading to overcapacity that hurts both companies (Porter, 1980; Zajac \& Bazerman, 1991). When the firm's director is a friend of a rival's CEO, however, both companies can exchange information through the director about their contingent decisions (e.g., their intention not to increase capacity if the rival does not increase capacity) (Zajac \& Bazerman, 1991) and avoid such misinterpretations, which can lead to more reliable cooperation between the firms.

In addition, board-friendship ties can be a source of competitive advantage over firms that lack such ties. Competitive advantage from these ties can take a relatively active form and a more passive form. The active form can derive from coordinated attacks by the connected firms against their common competitors, or coordinated responses to these competitors' moves to defend their positions better. For example, firms may jointly launch new products, advertising campaigns, promotions, or other moves that exploit weaknesses in a competitor's position, and/or initiate such attacks when the competitor is vulnerable (e.g., during a period of financial stress, change in leadership, or brand repositioning) (D'Aveni, 1994; Porter, 1980). The more passive form of competitive advantage from board-friendship ties derives from the tendency for competitors to avoid taking actions that would harm tied to firms or interfere with their plans, while giving less consideration to the adverse impact of their actions on firms to which they lack ties. For example, competitors may avoid introducing new products, advertising campaigns, or other strategic moves at a time that preempts a tied to firm's new product launch or brand repositioning, but not take such precautions for firms to which they lack ties.

Finally, although an outside director might have concerns about violating antitrust regulations by potentially facilitating interfirm collusion, the friendship ties that we examine here are below the radar of authorities, who typically focus on firm-level and industry-level characteristics that can be measured with public data (e.g., board interlocks and industry concentration) or public signals of collusion attempts (Crane, 2011). The friendship tie between an outside director and a rival's CEO is largely private information and cannot be observed from public documents, making it very difficult to detect the existence of such ties. In addition, interfirm communications through such an outside director are likely to occur informally between the director and the two involved CEOs, making such communications extremely difficult to detect. Our interviews with directors also confirm our expectation that directors are not particularly concerned about the risk of violating antitrust regulations when they facilitate communications between competing firms.

While appointing friends of rivals' CEOs can reduce competition, research suggests that the benefit of interfirm cooperation often depends on the level of competitive uncertainty in an industry. Competitive uncertainty is higher to the extent that top executives have difficulty reliably predicting or anticipating the actions of competitors or the consequences of these actions (i.e., in the absence of communication) (Soda \& Usai, 1999; Sutcliffe \& Zaheer, 1998). Similarly, competitive uncertainty arises from difficulties in inferring the intentions or plans of competitors from their actions alone (Porter, 1980). Moreover, the degree of competitive uncertainty in an industry is influenced by the level of market concentration. Competitive uncertainty tends to be low when there is a large number of similar firms or a very small number of dominating firms (Burt, 1982; Palmer, Barber, Zhou, \& Soysal, 1995; Pfeffer \& Salancik, 1978; Westphal et al., 2006). In the former case, the highly competitive environment reduces the likelihood that cooperation among a small number of firms would meaningfully influence the market outcome, reducing competitive uncertainty. In the latter case, the very small number of dominating firms can more easily infer each other's strategic intentions based on actions (Sugaya \& Takahashi, 2013). This not only reduces the likelihood of destructive competition but also makes tacit cooperation more feasible (Awaya \& Krishna, 2014; Harrington, 2005), 
reducing the importance of interfirm communications through board-friendship ties. Conversely, high competitive uncertainty in an industry is typically associated with an intermediate level of market concentration. In such a market, collusion without direct communications is difficult, but cooperation between firms can significantly influence market outcomes, increasing the value of communication through board-friendship ties in order to manage competitive uncertainty.

Research on director appointments suggests that firms often appoint directors to their boards to gain access to important resources or information (Hillman et al., 2009; Hillman \& Dalziel, 2003; Pfeffer \& Salancik, 1978). Our theory suggests that the appointments of outside directors who are friends of rival firms' CEOs help the firm manage competitive uncertainty by gaining access to important information about rival firms and achieve effective interfirm cooperation, which reduces the likelihood of destructive competition and provides a source of competitive advantage relative to firms that lack such ties. ${ }^{2}$ We therefore expect that the level of competitive uncertainty faced by a firm will be positively associated with the formation of board-friendship ties to its rivals.

\section{Hypothesis 1 (H1) There will be a positive association between the level of competitive uncertainty faced by a firm and the formation of board-friendship ties to CEOs of the firm's competitors.}

\subsection{1 | Rebuilding broken ties}

Expectancy perspectives on social networks indicate that the expected utility of social network ties affects the likelihood of both forming and maintaining such ties (Monge \& Contractor, 2003; Westphal \& Deephouse, 2011), where the maintenance of network ties includes the reconstitution of ties that are accidentally broken (Westphal et al., 2006). Our theoretical argument has suggested that board-friendship ties to competitors may help firms manage competitive uncertainty by facilitating interfirm cooperation that reduces the likelihood of destructive competition, while also providing a competitive advantage relative to firms that lack such ties. We therefore expect that firms are especially likely to reconstitute broken board-friendship ties to the extent that they face relatively high levels of competitive uncertainty. The focal firm A's board-friendship tie to firm B can be broken either when firm B changes its CEO or in less common cases when the outside director who is a friend of firm B's CEO departs from the focal board. Regardless of the specific reasons for the dissolution of a board-friendship tie, we expect that the firm will make efforts to rebuild the broken tie in order to manage competitive uncertainty. Thus,

\section{Hypothesis 2 (H2) There will be a positive association between the level of competitive uncertainty faced by a firm and the likelihood that a broken board-friendship tie to the CEO of the firm's competitor will be reconstituted.}

\subsection{The mediating role of executive search firms}

The process of identifying director candidates who are friends with competitors' CEOs can be complex and delicate. As discussed above, the friendship ties between other firms' CEOs and potential director candidates are not public information, and the focal board of directors may not feel comfortable approaching the CEOs of other firms for such private information. Executive search firms, however, are well suited to mediate this process (Khurana, 2002). According to a recent report by The

\footnotetext{
${ }^{2}$ Competitive uncertainty and competitive intensity are related but distinct constructs (Ang, 2008). Competitive intensity refers variously to the level or strength of competition, as opposed to the predictability of competition. Although competitive intensity is associated with uncertainty, at very high levels of intensity (e.g., under perfect competition), price is largely dictated by the market and uncertainty is reduced.
} 
Association of Executive Search and Leadership Consultants (AESC, 2011), executive search firms accounted for over $50 \%$ of the senior executive placements in the United States. However, there is only limited research on the role of executive search firms in influencing the selection of firm leaders (see review by Bonet, Cappelli, \& Hamori, 2013). Among the limited number of studies, little has been done to understand the influence of these headhunters on director selection or interfirm collusion.

We suggest that executive search firms play a key role in identifying director candidates who form board-friendship ties to the CEOs of competitors. Research on executive search firms suggests that they often serve as matchmakers who collect information from both parties to ease executive placements (Bidwell, 2011; Khurana, 2002). Khurana (2002) reported that search firms are especially likely to be used for searches that involve sensitive selection criteria. This is in part because search firms lend normative legitimacy to the selection process. Khurana (2002: 148) suggested that hiring a professional headhunter creates the appearance of an objective and broad-based search for candidates, while simultaneously enabling the board to "distance itself" from the search process. In particular, by relying on the headhunter to identify director candidates who have desirable social connections, such as friendship ties to the CEO of a competitor, the board distances itself from search criteria that, if discovered, could be viewed as illegitimate by some firm stakeholders.

Given that friendship ties between firm leaders are often not visible to third parties, and external perceptions of friendship can be unreliable (Kilduff \& Tsai, 2003), headhunters may need to solicit information about such ties from the CEOs of a firm's competitors. In fact, the search consultants whom we interviewed suggested that if they were searching for director candidates who have friendship ties to a particular leader, they would approach the leader directly about possible candidates. Consultants are vital intermediaries in the search process, because directors of the hiring firm would be reluctant to approach the CEO of a competitor directly about possible board candidates, and because headhunters at leading search firms are perceived to have particular expertise and experience in the "delicate social process" of eliciting sensitive information about external candidates for leadership positions (Khurana, 2002, p. 124).

Moreover, in conversing with the CEO of a competitor about possible board candidates, the consultant can discretely signal the purpose of the appointment. As one CEO whom we interviewed suggested, "if [a headhunter] asks you whether [a board candidate] is someone you know well and trust, and says this is important, and you say yes they're a friend and I trust them and recommend them, you're really saying 'signal received'." Such subtle exchanges are an example of what linguists call "off-record indirect speech" (Lee \& Pinker, 2010, p. 785), in which the speaker elicits information and cooperation of a potentially illicit nature, without overtly describing the desired behavior (e.g., exchange of strategic information), to maintain "plausible deniability" for both parties (Pinker, Nowak, \& Lee, 2008, p. 834). Our arguments above thus suggest that a headhunter's solicitation of director candidates from a competitor's CEO will at least partially mediate the formation of boardfriendship ties, as well as the reconstitution of these ties when broken.

Hypothesis 3a (H3a) A headhunter's solicitation of director candidates from a competitor's CEO will mediate the positive relationship between the level of competitive uncertainty and the formation of board-friendship ties to CEOs of the firm's competitors.

Hypothesis $3 \mathbf{b}(\mathbf{H 3 b})$ A headhunter's solicitation of director candidates from a competitor's CEO will mediate the positive relationship between the level of competitive uncertainty and the likelihood that a broken board-friendship to the CEO of the competitor will be reconstituted. 


\section{3 | Performance effects of board-friendship ties to competitors}

Industrial economics has long suggested that collusion helps firms enhance their profitability (Stigler, 1964). Theory and research on interfirm competition suggests that effective communications among rivals about their contingent decisions can help reduce competition (Ingram \& Roberts, 2000; Uzzi, 1997; Zajac \& Bazerman, 1991). When a firm's outside directors have friendship ties to some rivals, such ties have the potential to effectively facilitate interfirm collusion and reduce competition with them, resulting in better financial performance. In particular, when a firm is connected to some rivals through board-friendship ties, they are in a position to share information about pricing, production, and other strategic plans through such ties, and to obtain information about their rivals' plans, potentially enabling them to better compete with other firms that lack such ties. In addition, a firm's boardfriendship ties to rivals may facilitate the mutual sharing of information about their common suppliers and buyers, reducing information asymmetry and helping them negotiate better exchange terms than competitors that do not have board-friendship ties.

Efforts to coordinate pricing and production levels through board-friendship ties are also more likely to be successful due to the nature of such ties. As discussed above, any defection by the rival CEO would damage the friendship relation, since it would put the director's social capital and reputation at risk, among fellow board members and within the broader director labor market (Westphal \& Khanna, 2003; Westphal \& Stern, 2007). Similarly, the focal firm is unlikely to defect from an informal agreement or understanding reached through its outside director who is a friend of a rival's CEO - any defections need to be first approved by or at least revealed to the outside director who can be expected to object and then notify the rival's CEO. Moreover, directors' friendship ties to rivals' CEOs can facilitate the mutual exchange of specific and fine-grained information (Uzzi, 1997) about strategic plans more effectively than impersonal, public signaling of strategic plans between firms. Public signaling is significantly constrained by antitrust concerns, such that firms must signal their plans in vague terms that are easily missed or misinterpreted (Porter, 1980). As a result, the frequency of public signaling of strategic plans is suppressed in most industries (Porter, 2005), and when attempted, it is frequently unsuccessful in eliciting cooperation (Harrington, 2005). Friends of a competitor CEO can send more specific, high-fidelity signals about the competitor's contingent plans (e.g., "my understanding is that they will not cut price if we maintain ours,") reducing the perceived risk of cooperation.

To the extent that a firm can effectively coordinate its major decisions with competitors through board-friendship ties to their CEOs, it can enjoy a higher degree of market power relative to consumers and suppliers, leading to better financial performance. When a firm's outside directors have friendship ties to the CEOs of the firm's competitors, the firm can better avoid or reduce destructive competition, such as by decreasing the likelihood of price wars, avoiding bidding wars for supplies, or cooperatively expanding production capacities when needed (Ingram \& Roberts, 2000; Westphal et al., 2006). Exchanging information with rivals about common suppliers and buyers may also permit the firm to achieve better negotiation outcomes with these firms. Our theoretical argument has also suggested that board-friendship ties provide a source of competitive advantage relative to firms that lack such ties. The connected firms can engage in coordinated attacks against common competitors, or coordinated responses to their competitors' moves (D'Aveni, 1994; Porter, 1980). Competitive advantage from board-friendship ties may also take a more passive form, as firms avoid taking actions that would disrupt the plans of tied to firms, and give little consideration to the adverse impact of their actions on firms to which they lack ties. Thus, friendship ties between a firm's outside directors and CEOs of competitors may tend to facilitate mutual information sharing and coordination with competitors that ultimately improves its financial performance. 
Hypothesis 4 (H4) Board-friendship ties to CEOs of the firm's competitors will be positively associated with the financial performance of the firm.

\section{2 | METHOD}

\section{1 | Sample and data collection}

The population for this study included large and medium-sized public companies in the United States with more than $\$ 100$ million in annual revenues. We measured board-friendship ties and several other key constructs with survey responses from directors and CEOs. The sample frame for this survey included outside directors at 900 firms in the population where at least one board member had responded to a prior survey by the first author. Firms in the sample frame were representative of the population with respect to each of the archival variables described below.

We took several measures to ensure the quality of the survey and boost participation rates, including a qualitative pretest of the survey instrument that involved in-depth interviews with 26 current or former directors from firms in the population (see Appendix). We measured friendship ties using responses of directors who serve on the board's nominating committee, since our interviews suggested that these directors tend to be especially knowledgeable about the friendship ties of fellow board members to leaders of other firms (we provide further evidence for this assumption below). Firms were included in the final sample if at least two members of the nominating committee agreed to participate in the study, which involved responding to surveys annually from 2007 to 2013 . We required participation from at least two members of the nominating committee in order to assess the inter-rater reliability of our survey measures. This resulted in an initial sample of 552 firms. If a director stopped participating during the study (e.g., due to turnover), we sought the participation of other committee members. Forty-three firms were dropped from the sample due to inadequate participation during the study period, leaving a final sample of 509 firms ( $57 \%$ of the initial sample frame). ${ }^{3}$ To further assess inter-rater reliability, we also surveyed (a) other directors at firms in the sample and (b) CEOs in the same industry as a participating firm who were perceived by members of the firm's nominating committee to have a friendship tie to a director of the firm (39\% response rate).

We tested for survey nonresponse bias using the Kolmogorov-Smirnov equality of distributions test (Gibbons \& Chakraborti, 2011). Results indicated that participating firms were not significantly different from nonparticipants on any of the independent or dependent variables derived from archival data sources ( $p$ values ranged from 0.22 to 0.81 ). Similarly, participating directors were not significantly different from nonparticipants with respect to age, tenure, management experience, or experience as a director ( $p$ values ranged from 0.37 to 0.64 ).

We obtained demographic and board membership data on CEOs and directors from multiple sources, including BoardEx, Compact Disclosure, Capital IQ, Marquis' Who's Who, The Dun and Bradstreet Reference Book of Corporate Management, The Social Register, proxy statements, and annual reports. We obtained firm financial data from COMPUSTAT and CRSP. Archival data for the measure of industry constraint were obtained from the Bureau of Economic Analysis. Security analyst reports were obtained from Investex, supplemented by Zacks.

\footnotetext{
${ }^{3}$ We conducted separate analyses for the larger sample of firms in which at least one member of the nominating committee participated, and the results were substantively unchanged from those presented below, with respect to the statistical significance and magnitude of the hypothesized effects.
} 


\section{2 | Measures}

\subsection{1 | Board-friendship ties}

Consistent with much prior research on social networks, we measured friendship ties directly with survey questions (Brass, 1984; Ibarra \& Andrews, 1993; Krackhardt \& Kilduff, 1999). As noted above, our preliminary interviews suggested that directors who serve on the board's nominating committee tend to be particularly knowledgeable about the friendship ties of fellow board members to leaders of other firms. ${ }^{4}$ The survey prompted these directors to indicate friendships between each outside director on the board and each CEO of competitors, buyer firms, and supplier firms, with the directors and firms listed by name. ${ }^{5}$

We conducted several analyses to assess the inter-rater agreement and convergent validity of this measure. First, we compared the responses of nominating committee members at the same firm, which showed a high rate of agreement between directors about whether other board members had friendship ties to particular CEOs in the same industry (97\%). In a second set of analyses, we compared the responses of nominating committee members with (a) the responses of other participating directors $\left(d_{1 \ldots}\right.$ ${ }_{N}$ ) about whether the participating director $d$ had friendship ties to particular CEOs in the industry and (b) the responses of participating CEOs at other firms about whether they had friendship ties to directors on the focal board. Both analyses showed a similarly high level of inter-rater agreement (96 and 95\%, respectively). ${ }^{6}$ There were also strong correlations between our primary measure of friendship, based on the responses of nominating committee members, and the responses of CEOs and other directors to 5-point scales that gauge key features of friendship ties referenced in our theoretical argument (cf., Hays, 1985; Krackhardt, 1992; Uzzi, 1997), including trust ("To what extent do you feel you can trust this person?"), and willingness to disclose sensitive information ("To what extent do you feel comfortable disclosing sensitive information to this person?") (correlations ranged from .74 to .87 ). ${ }^{7}$ These analyses provide evidence for convergent validity, as well as inter-rater reliability of our primary measure.

In the main analyses, we measured the formation of board-friendship ties to CEOs of competitors as the number of outside directors appointed to the focal board during the subsequent year who were friends with the CEO of a competitor. ${ }^{8}$ In separate analyses, we measured the formation of ties over longer time periods ( 2 years or 3 years), and the hypothesized results were unchanged. A boardfriendship tie to the CEO of a competitor was coded as broken if an outside director was friends with the CEO at time $t-1$, and there was turnover of the CEO and/or director during the subsequent 12 months (i.e., between time $t-1$ and time $t$ ). In the primary analyses, we measured reconstitution of

\footnotetext{
${ }^{4}$ Our interviews indicated that members of the nominating committee commonly exchange information about the ties of fellow board members and board candidates to leaders of other firms during the director selection process, and that headhunters often seek and provide additional information on such ties to the committee. Moreover, knowledge of such ties accumulates over the course of multiple searches and is passed on from experienced committee members and consultants to their less experienced colleagues.

${ }^{5}$ Consistent with longstanding approaches to measuring friendship ties in the social network literature (cf., Krackhardt \& Kilduff, 1999; Krackhardt \& Porter, 1985), respondents filled out a matrix with CEOs in the industry and some leaders outside the industry listed on the vertical axis, and directors of the focal firm on the horizontal axis. Respondents were asked to indicate "whether each individual is an acquaintance or a personal friend of [the director]."

${ }^{6}$ Inter-rater agreement was adequately high even in industries with relatively low concentration. For example, among firms in industries that lie in the bottom quartile of industry concentration, the rate of agreement between nominating committee members and other participating directors $\left(d_{1 \ldots N}\right)$ about whether the director $d$ had friendship ties to particular CEOs in the industry was $92 \%$; similarly, the rate of agreement between committee members and participating CEOs at other firms about whether they had friendship ties to directors on the focal board was $91 \%$.

${ }^{7}$ Our primary measure was also correlated with a 5-point scale that gauges the closeness of respondents' personal relationships (Swart et al., 2011; Zeng \& Xie, 2008) with CEOs at other firms (“To what extent do you feel close to this person?”).

${ }^{8}$ Moreover, in the main analyses, this measure is based on the survey responses of one nominating committee member, selected at random. In separate analyses, we used the average number of ties reported by respondents, and the results were essentially identical, which reflects the high inter-rater reliability reported above.
} 
broken ties over the subsequent year. That is, a broken board-friendship tie between an outside director of the focal firm $(F)$ and the CEO of a competitor firm (Alter) was coded as reconstituted if a new outside director of $F$ was friends with the CEO of Alter at time $t+1$. Again, in separate analyses, we measured reconstitution of broken ties over longer time periods ( 2 years or 3 years), and the hypothesized results were unchanged. As noted above, in a large majority of cases, friendship ties between outside directors and CEOs of competitors were broken due to turnover of the CEO (88\%).

\subsection{2 | Competitive uncertainty}

We used multiple measures of competitive uncertainty. First, we used a multi-item survey scale that directly measures competitive uncertainty as defined in our theoretical argument. As discussed above, competitive uncertainty is relatively high to the degree that top executives have difficulty reliably predicting or anticipating the actions of competitors or the consequences of these actions (i.e., in the absence of communication with competitors) (Soda \& Usai, 1999; Sutcliffe \& Zaheer, 1998). Similarly, competitive uncertainty derives from difficulties in inferring the intentions or plans of competitors from their actions alone (Porter, 1980). The survey scale items are listed in the Appendix, and they directly reflect our theoretical conceptualization of competitive uncertainty (e.g., "How predictable would the actions of competitors be, in the absence of measures to reduce the uncertainty?"..."To what extent would it be difficult to anticipate the actions of competitors, without strategies to reduce the uncertainty?"..."To what extent would it be difficult to infer the intentions or plans of competitors from their actions alone?"). Inter-item reliability of the scale was acceptably high $(\alpha=0.92)$. There was also a high level of inter-rater agreement between respondents at the same firm: Weighted Kappa coefficients for the survey items ranged from 0.83 to 0.89 (Fleiss, 1981). We developed this measure for each company in the sample in each year of the study.

We developed a second measure of competitive uncertainty by conducting a text analysis of security analyst reports for companies in the sample frame in each year of the study. We screened for sentences in the reports that referred to competitive uncertainty using a dictionary of synonymous words and phrases (available from the authors on request). We then had two coders read all reports that contained at least one reference to competitive uncertainty as identified in the text analysis, and assess whether the report indicated that the firm faced (a) a low level of competitive uncertainty, (b) some competitive uncertainty, or (c) a high level of competitive uncertainty, as defined in our theoretical argument. ${ }^{9}$ There was a high rate of agreement between the coders about the level of uncertainty (84\%) described in the reports, and a very high level of agreement about whether the reports indicated that the focal firm faced at least some competitive uncertainty (95\%). For our primary analyses, we then calculated the percentage of analyst reports in each year which suggested that the focal firm faced at least some competitive uncertainty. In separate analyses, we restricted this measure to cases in which both coders agreed that the report suggested high competitive uncertainty, and the hypothesized results were unchanged.

As our third measure of competitive uncertainty, we used the mean-deviated concentration level of the focal firm's primary industry, following a long line of prior research (Burt, 1983; Palmer et al., 1995; Pfeffer \& Salancik, 1978; Westphal et al., 2006). As discussed above, these prior studies suggest that competitive uncertainty tends to be relatively high in industries with an intermediate level of market concentration. We first calculated the absolute value of the difference between the four-firm

\footnotetext{
${ }^{9}$ We followed procedures that are believed to provide a more meaningful assessment of intercoder reliability (Holsti, 1968; Weber, 1985). The coders had different backgrounds: One was an MBA student with a background in Finance, and the other was an undergraduate business student with a focus on marketing; neither was a coauthor on the paper. The coders were provided with the description of competitive uncertainty from our theoretical argument, but were not provided with a detailed coding guide or coaching that could inflate estimates of reliability.
} 
concentration ratio of the focal firm's primary industry (i.e., the total market share of the four largest firms) and the mean concentration ratio for all industries represented in the sample frame (Burt, 1983; Palmer et al., 1995; Westphal et al., 2006). This variable was then inverted so that higher values correspond to medium levels of industry concentration (indicating higher levels of competitive uncertainty).

Factor analysis showed that all of these measures - the survey scale, the measure derived from content analysis, and the measure of market concentration-loaded on the same factor as expected, with factor loadings above .6 for each of the measures. We estimated factor scores using the regression method (the hypothesized results were unchanged using the Bartlett method). As discussed below, in further analyses, we used each of the three measures in separate models, and again the results were unchanged (as would be expected from the high factor loadings of the measures).

\subsection{3 | Headhunter's solicitation of director candidates}

We used a series of survey questions to determine whether a headhunter solicited director candidates from a competitor's CEO. One question asked nominating committee members, "From whom did [the headhunter] solicit candidates for a position on the board during the previous twelve months [list positions or names]?" Another question asked, "Approximately when did [the headhunter] solicit candidates from this person?" A parallel set of questions was included in the CEO survey to assess inter-rater reliability. There was a high level of agreement between respondents at the same firm about whether the focal firm's headhunter solicited director candidates from a competitor's CEO (95\%). For cases of broken ties, there was a similarly high level of agreement between nominating committee members and Alter's CEO about whether the focal firm's headhunter solicited the CEO for board candidates on behalf of the focal firm (95\%). To test H3a regarding the mediating role of headhunters in tie formation, we created a dichotomous variable coded " 1 " if responding directors indicated that the focal firm's headhunter solicited the CEO of a competitor for board candidates on behalf of the focal firm during the current year. To test $\mathrm{H} 3 \mathrm{~b}$ regarding the mediating role of headhunters in tie reconstitution, we created a dichotomous variable coded " 1 " if responding directors indicated that the focal firm's headhunter solicited the CEO of Alter for board candidates on behalf of the focal firm during the year after a board-friendship tie to Alter was broken.

\subsection{4 | Firm performance}

In the primary analyses, we measured the focal firm's financial performance as industry-adjusted return on assets (ROA) in year $t+1$. In separate models, we used industry-adjusted return on equity (ROE) and Tobin's q as alternative measures of firm performance, and the hypothesized results were unchanged. The results were unchanged when the performance measures were not adjusted for industry, and the results were also robust to estimating ROA, ROE, or Tobin's q in year $t+2$ or $t+3$. Given potential concerns with ratio-based measures (Wiseman, 2009), we ran separate models that estimate net income while controlling for total assets. The hypothesized results were unchanged, and are reported separately below.

\subsection{5 | Control variables}

Given that poor firm performance could motivate the appointment of directors who have friendship ties to competitors, we controlled for recent firm performance in models of board-friendship ties, measured as ROA in year $t-1$. We also controlled for firm size, measured as the logged value of total sales in year $t-1$ (Crossland \& Chen, 2013). In addition, we controlled for other kinds of ties between firms. We controlled for common board appointments between directors of the focal firm and CEOs 
of competitors. Although such ties are less common and much weaker than board-friendship ties, and are unlikely to substitute for such ties, they could be used to identify director candidates who are friends of the CEO. Given some evidence that board ties are correlated with other formal ties between firms, such as joint ventures, interfirm stockholding, or common ownership (Palmer et al., 1986), we included a dichotomous control that indicates whether such relationships existed between the focal firm and competitors. In other analyses, we included a separate control for common ownership, and the results were unchanged. We also controlled for board size in models of board-friendship ties. In estimating the reconstitution of broken ties, we included a dichotomous variable that indicates whether ties were broken due to CEO or director turnover. Moreover, we controlled for the focal firm's dependence on resource providers, using the measure developed and validated by Westphal et al. (2006) (see Appendix for a complete description of this measure). In separate analyses, we used Burt's (1983) measure of industry constraint, and the hypothesized results were unchanged.

Although our theory focuses on board-friendship ties that are created through appointments to the focal firm's board, as these ties are more under the focal firm's control, our theory would also imply that the focal firm is likely to benefit when the CEO's friends serve on the boards of competitors. Thus, in models of firm performance, we controlled for the number of friends of the focal CEO who serve on the boards of competitors. We also controlled for the number of board-friendship ties to CEOs of resource providers, as well as the number of friends of the focal CEO who serve on the boards of resource providers.

We controlled for key indicators of resource allocation in models of performance (Chatterjee \& Hambrick, 2007; Chen \& Hambrick, 2012; Finkelstein \& Hambrick, 1990), including the advertising ratio (advertising/sales), the research and development $(\mathrm{R} \& \mathrm{D})$ ratio ( $R \& D /$ sales), financial leverage (debt/equity), and capital expenditure (as a percentage of sales) in year $t-1$; the hypothesized results were also robust to controlling for the liquidity ratio. We controlled for the log of sales in year $t-1$, and in random effects models, we included a dichotomous control for whether the focal firm operates in only one industry. We controlled for survey measures of friendship ties between the focal firm's CEO and the CEOs of competitors and resource providers that parallel our measures of boardfriendship ties. There was high agreement between directors on the nominating committee and CEOs themselves about the CEO's friendship ties to leaders of other firms (94\%). We also included both year and industry dummy variables (using two-digit SIC codes) in all models. In separate models, we controlled for industry-adjusted ROA in the prior year, and the hypothesized results were unchanged.

\section{3 | Analysis}

We used panel data to test the effects of competitive uncertainty on the formation of board-friendship ties. As noted above, the primary dependent variable for $\mathrm{H} 1$ is the number of outside directors appointed to the focal board during the subsequent year who were friends with the CEO of a competitor. Thus, the unit of analysis in tests of $\mathrm{H} 1$ is the firm-year $(N=3,054)$. Since we use panel data and the dependent variable is a count without overdispersion, we used random-effects poisson regression analysis. ${ }^{10}$ The Hausman test indicated that there was not a systematic difference between the random-effects and fixed-effects specifications. Thus, we used random effects in the primary models. In separate models, we tested the hypotheses using GEE regression with clustered robust standard errors, and the hypothesized results were unchanged from those presented below. In further analyses, we estimated a Heckman poisson model (Terza, 1998) in which the selection equation estimates participation in the study among the larger sample frame (see Appendix for a description of this model).

\footnotetext{
${ }^{10}$ The likelihood ratio test of overdisperson $(\alpha=0)$ was not statistically significant $(p=0.491)$.
} 
None of the independent variables from the main equation were significant in the selection equation. Certo, Busenbark, Woo, and Semadeni (2016) state that the independent variable of interest must be a significant predictor in the selection equation for sample selection bias to exist. In any event, as discussed below, the hypothesized effect of competitive uncertainty on board-friendship ties remained strongly significant in this model.

In the main analyses, we tested $\mathrm{H} 2$ regarding the reconstitution of broken board-friendship ties for the subsample of ties to CEOs of competitors $(N=1,065)$ that were broken in the prior year. We used logit regression with clustered robust standard errors. Again, in further analyses, we estimated a Heckman probit model in which the selection equation estimates the likelihood of a broken tie among the full sample of board-friendship ties (see Appendix). None of the independent variables from the main equation were significant in the selection equation, which provides some indication that sample selection bias is not affecting our results (Certo et al., 2016; Wooldridge, 2010). In any case, as discussed below, the effect of competitive uncertainty on the likelihood of reconstituting broken boardfriendship ties remained strongly significant in the model.

We tested the mediating effect of a headhunter's solicitation of director candidates from a competitor's CEO using the product of coefficients method with Sobel-Goodman standard errors (MacKinnon, Lockwood, Hoffman, West, \& Sheets, 2002). Although this method can be overly conservative with inflated type II errors, MacKinnon's simulations showed that such errors are small for large samples. Nevertheless, we conducted separate analyses using the bootstrapping method with bias-corrected estimates (MacKinnon, Lockwood, \& Williams, 2004; also Preacher \& Hayes, 2008), based on 5,000 bootstrapped samples from the dataset. The hypothesized results were very similar to those reported below.

We used fixed-effects regression analysis with clustered robust standard errors to test the hypothesized effects of board-friendship ties on firm performance. The Durbin-Watson and BreuschGodfrey tests indicated that autocorrelation was not significant.

\section{3 | RESULTS}

Descriptive statistics are included in Table 1, and bivariate correlations are provided in Table 2. As shown in Table 1, while the average number of board-friendship ties to CEOs of competitors was 2.2, friendship ties between the focal firm's CEO and CEOs of competitors were comparatively rare (mean of 0.66). Moreover, 68\% of broken board-friendship ties to CEOs of competitors were reconstituted. By comparison, Westphal et al.'s (2006) analysis showed that only $34 \%$ of broken friendship ties between the focal firm's CEO and CEOs of competitors were reconstituted. As discussed above, moreover, reconstitution of friendship ties between CEOs occurs over a much longer time span. Westphal et al. (2006) measured reconstitution over a 3-year time window; very few broken ties were repaired within 1 year. By contrast, board-friendship ties were reconstituted at a much higher rate (a majority within 1 year).

Table 3 includes the results of poisson regression models of board-friendship ties to CEOs of competitors. H1 predicted that the level of competitive uncertainty would be associated with the formation of board-friendship ties to CEOs of the firm's competitors. The results provide support for this hypothesis: there is a positive association between our measure of competitive uncertainty and the subsequent formation of board-friendship ties to CEOs of the firm's competitors $(p<0.001)$. Separate analysis also confirmed that the marginal effect of competitive uncertainty is statistically significant over the full range of sampled observations; z-statistics of the marginal effects ranged from 9.61 to 16.70. The magnitude of the effect is also considerable. For example, all else equal, when 
TABLE 1 Descriptive statistics

\begin{tabular}{|c|c|c|}
\hline Variable & Mean & $S D$ \\
\hline 1. Competitive uncertainty & $0.00^{\mathrm{a}}$ & 0.98 \\
\hline 2. Concentration of buyer/supplier industries & 40.88 & 19.04 \\
\hline 3. Perceived value of resources provided by exchange partners & $0.00^{\mathrm{a}}$ & 0.97 \\
\hline 4. Return on assets (ROA) & 0.04 & 0.08 \\
\hline 5. Log of sales & 7.44 & 1.66 \\
\hline 6. Common board appointments between directors and chief executive officer (CEO) & 1.37 & 2.09 \\
\hline 7. Formal tie & 0.37 & 0.48 \\
\hline 8. CEO versus director turnover & 0.88 & 0.33 \\
\hline 9. Debt to equity ratio & 1.86 & 10.06 \\
\hline 10. Research and development $(\mathrm{R} \& \mathrm{D})$ ratio & 0.02 & 0.05 \\
\hline 11. Advertising ratio & 0.01 & 0.03 \\
\hline 12. Capital expenditure & 0.09 & 0.17 \\
\hline 13. Friendship ties $\mathrm{b} / \mathrm{w} \mathrm{CEO}$ of focal firm and CEOs of competitors & 0.66 & 0.85 \\
\hline 14. Friendship ties b/w CEO of focal firm and CEOs of firms in buyer/supplier industries & 0.98 & 0.96 \\
\hline 15. Board-friendship ties to CEOs of competitors & 2.2 & 3.0 \\
\hline 16. Focal CEO's friends on boards of competitors & 2.2 & 3.1 \\
\hline 17. Focal CEO's friends on boards of resource providers & 2.6 & 3.9 \\
\hline 18. Board size & 9.79 & 3.39 \\
\hline 19. Reconstitution of broken board-friendship tie to CEO of competitor & 0.68 & 0.47 \\
\hline
\end{tabular}

a Variables with a mean of zero are factor scores derived from factor analysis. Factor scores are a weighted sum of variables that comprise the measure, with the variable scores standardized and weighted by their factor loadings (Grice \& Harris, 1998).

competitive uncertainty is one standard deviation greater, the incidence rate ratio for the number of board-friendship ties to competitors is approximately 2.5 times greater.

The results of logit regression models of the reconstitution of broken board-friendship ties are provided in Table 4, and they provide support for H2. As shown in Model 1 of the table, there is a positive relationship between competitive uncertainty and the likelihood of reconstituting a broken board-friendship tie to the CEO of a competitor firm. Separate analysis confirmed that the marginal effect of competitive uncertainty is statistically significant over the full range of sampled observations; z-statistics of the marginal effects ranged from 10.09 to 19.30 .

The mediating effects of headhunter solicitation of director candidates are displayed in Table 5 . Consistent with $\mathrm{H} 3 \mathrm{a}$, the hypothesized relationship between competitive uncertainty and the subsequent formation of board-friendship ties to CEOs of competitors is significantly mediated by headhunter solicitation of director candidates from a competitor's CEO $(p<0.001)$. H3b is also supported: the relationship between competitive uncertainty and reconstitution of a broken boardfriendship tie to the CEO of a competitor is also significantly mediated by headhunter solicitation of director candidates from the competitor's CEO $(p<0.001)$.

The results of fixed-effects regression models of firm performance are provided in Table 6, and they provide support for the hypothesized effects of board-friendship ties on firm performance. Consistent with $\mathrm{H} 4$, the results indicate a positive effect of friendship ties between a firm's outside directors and CEOs of the firm's competitors on firm profitability at $p<0.001$. Moreover, the magnitude of these effects is noteworthy. An increase of one board-friendship tie to competitors is associated with an average increase in ROA of $1.6 \%$, which corresponds to an average increase in net income of approximately $\$ 134$ million. As noted above, in light of potential concerns about ratio-based 
TABLE 2 Pearson correlation coefficients

$\begin{array}{llllllllllll}\text { Variable } & 1 & 2 & 3 & 4 & 5 & 6 & 7 & 8 & 9 & 10 & 11\end{array}$

Models of board-friendship ties $(N=3,054)$

1. Competitive uncertainty

2. Concentration of buyer/supplier industries

$\begin{array}{rrrrrrrrr}.02 & & & & & & & \\ .03 & -.01 & & & & & & \\ & & & & & & & \\ -.07 & -.18 & .05 & & & & & \\ -.02 & -.04 & -.01 & .04 & & & & \\ .02 & -.03 & .01 & .04 & .02 & & & \\ & & & & & & & \\ .05 & .08 & .07 & .02 & .03 & .03 & & \\ -.03 & -.01 & -.02 & .03 & .14 & .12 & .10 & \\ .3234 & .22 & .05 & -.12 & .09 & .02 & -.08 & .10\end{array}$
partners

4. Return on assets (ROA)

5. Log of sales

6. Common board appointments between directors and chief executive officers (CEOs)

7. Formal ties

8. Board size

9. Board-friendship ties to CEOs of competitors

Models of reconstitution of broken board-friendship ties $(N=1,065)$

1. Competitive uncertainty

2. Concentration of buyer/supplier industries

.02

$.03-.01$ partners

4. ROA

5. Log of sales

6. Common board appointments between directors and $\mathrm{CEO}$ of other firm

7. Formal tie to other firm

8. CEO versus director turnover

9. Board size

10. Reconstitution of broken board-friendship tie to CEO of competitor

Models of firm performance $(N=3,054)$

1. Board-friendship ties to CEOs of competitors

2. Board-friendship ties to CEOs of firms in buyer/ supplier industries

3. Log of sales

4. Debt to equity ratio

5. Research and development (R\&D) ratio

6. Advertising ratio

7. Capital expenditure

8. Focal CEO's friends on boards of competitors

9. Focal CEO's friends on boards of resource providers

10. Friendship ties b/w CEO of focal firm and CEOs of competitors

11. Friendship ties $\mathrm{b} / \mathrm{w}$ CEO of focal firm and CEOs of firms in buyer/supplier industries

12. Industry-adjusted ROA

$$
\begin{array}{rrrrrrrrrrr}
-.06 & -.17 & .05 & & & & & & \\
-.03 & -.04 & -.01 & .04 & & & & & \\
.03 & -.02 & .02 & .03 & .02 & & & & \\
& & & & & & & & \\
.05 & .09 & .08 & .01 & .05 & .04 & & & \\
.054 & .02 & .00 & -.01 & .01 & .00 & .01 & & \\
-.02 & -.01 & -.02 & .02 & .12 & .11 & .10 & -.05 & \\
.36 & .18 & .06 & -.10 & .06 & .03 & -.09 & .04 & .13
\end{array}
$$

$$
\begin{array}{rrrrrrrrrrrrrrrr}
.08 & .07 & & & & & & & & \\
.02 & .00 & .06 & & & & & & & \\
-.08 & -.06 & -.04 & .02 & & & & & & \\
-11 & -.07 & -.01 & .02 & .01 & & & & & \\
-.06 & -.05 & .02 & .03 & -.02 & -.04 & & & & \\
.05 & -.02 & .06 & -.01 & -.04 & -.09 & -.04 & & & & \\
-.01 & -.03 & .06 & -.02 & -.02 & -.03 & -.02 & .02 & & & \\
-.03 & -.01 & .03 & .01 & -.02 & .03 & .02 & -.03 & -.01 & & \\
& & & & & & & & & & \\
-.01 & -.04 & .05 & .02 & -.01 & .01 & .02 & .01 & -.03 & .10 & \\
& & & & & & & & & & \\
.32 & .29 & .06 & .03 & -.14 & -.11 & -.07 & .26 & .02 & .05 & .07
\end{array}
$$

measures, we ran a separate analysis that estimated the effect of board-friendship ties on net income, controlling for firm assets. As reported in Table A1 of the Appendix, the hypothesized results were fully consistent with the results for ROA. 
TABLE 3 Poisson regression model of board-friendship ties to chief executive officers (CEOs) of competitors ${ }^{\mathrm{a}}$

\begin{tabular}{|c|c|}
\hline Independent variable & \\
\hline 1. Competitive uncertainty & $\begin{array}{l}0.397[.000] \\
(0.027)\end{array}$ \\
\hline $\begin{array}{l}\text { 2. Resource dependence (concentration of buyer/supplier industry } \times \text { perceived value of resources provided } \\
\text { by exchange partner) }\end{array}$ & $\begin{array}{l}0.004[.014] \\
(0.002)\end{array}$ \\
\hline 3. Concentration of buyer/supplier industries & $\begin{array}{l}0.003[.038] \\
(0.002)\end{array}$ \\
\hline 4. Perceived value of resources provided by exchange partners & $\begin{array}{l}0.039[.188] \\
(0.029)\end{array}$ \\
\hline 5. Return on assets (ROA) & $\begin{array}{l}-1.478[.001] \\
(0.463)\end{array}$ \\
\hline 6. Log of sales & $\begin{array}{l}0.031[.053] \\
(0.016)\end{array}$ \\
\hline 7. Common board appointments between directors and CEOs & $\begin{array}{l}0.023[.086] \\
(0.013)\end{array}$ \\
\hline 8. Formal ties & $\begin{array}{l}-0.011[.013] \\
(0.004)\end{array}$ \\
\hline 9. Board size & $\begin{array}{l}0.020[.020] \\
(0.009)\end{array}$ \\
\hline Constant & $\begin{array}{l}0.320[.034] \\
(0.151)\end{array}$ \\
\hline Wald $\chi^{2}$ & 76.89 \\
\hline$N$ & 3,054 \\
\hline
\end{tabular}

${ }^{a} p$ values are in brackets (two-tailed tests); standard errors are in parentheses. Industry and year dummies are included.

TABLE 4 Logit regression model of the reconstitution of broken board-friendship ties ${ }^{\mathrm{a}}$

\section{Independent variable}

1. Competitive uncertainty

$1.187[.000]$

2. Resource dependence (concentration of buyer/supplier industry $\times$ perceived value of resources provided by exchange partner)

$0.012[.018]$

$(0.005)$

3. Concentration of buyer/supplier industries

4. Perceived value of resources provided by exchange partners

5. Return on assets (ROA)

6. Log of sales

7. Common board appointments between directors and chief executive officer (CEO) of other firm

8. Formal tie to other firm

9. CEO versus director turnover

10. Board size

Constant

a $p$ values are in brackets (two-tailed tests); standard errors are in parentheses. Industry and year dummies are included. 
TABLE 5 Mediating effects of headhunter solicitation of director candidates ${ }^{\mathrm{a}}$

\begin{tabular}{|c|c|}
\hline Mediated path & $\mathbf{z}$ \\
\hline $\begin{array}{l}\text { Competitive uncertainty } \stackrel{+}{\rightarrow} \text { headhunter solicitation of director candidates from chief executive officer } \\
\quad \text { (CEO) of a competitor } \underset{\rightarrow}{\rightarrow} \text { formation of board-friendship ties to CEOs of competitors }{ }^{b}\end{array}$ & $\begin{array}{l}0.036[.000] \\
(0.003)\end{array}$ \\
\hline $\begin{array}{l}\text { Competitive uncertainty } \stackrel{+}{\rightarrow} \text { headhunter solicitation of director candidates from CEO of other firm } \stackrel{+}{\rightarrow} \text { reconstitution } \\
\text { of broken board-friendship tie to CEO of competitor }{ }^{c}\end{array}$ & $\begin{array}{l}0.088[.000] \\
(0.005)\end{array}$ \\
\hline
\end{tabular}

${ }^{a} p$ values are in brackets (two-tailed tests); standard errors are in parentheses.

${ }^{\mathrm{b}} N=3,054$.

${ }^{\mathrm{c}} N=1,065$.

TABLE 6 Fixed-effects regression analysis of firm performance ${ }^{\mathrm{a}}$

\section{Independent variable}

1. Board-friendship ties to chief executive officers (CEOs) of competitors

$0.016[.000]$

(0.001)

2. Board-friendship ties to CEOs of firms in buyer/supplier industries

$0.015[.000]$

$(0.0008)$

3. Friendship ties between CEO of focal firm and CEOs of competitors

$0.005[.057]$

(0.003)

4. Friendship ties between CEO of focal firm and CEOs of firms in buyer/supplier industries

$0.006[.034]$

(0.003)

5. Focal CEO's friends on boards of competitors

$0.013[.000]$

$(0.001)$

6. Focal CEO's friends on boards of resource providers

$0.0001[.854]$

$(0.0007)$

7. Log of sales

$0.0018[.252]$

(0.0016)

8. Debt to equity ratio

$0.0003[.087]$

(0.0002)

9. Research and development $(\mathrm{R} \& \mathrm{D})$ ratio

$-0.228[.003]$

(0.077)

10. Advertising ratio

$-0.394[.013]$

(0.158)

11. Capital expenditure

$-0.015[.132]$

(0.010)

Constant

${ }^{\text {a }} N=3054 . p$ values are in brackets (two-tailed tests); standard errors are in parentheses. Year dummies are included.

To examine the potential for endogeneity in our models, we estimated impact threshold for a confounding variable (ITCV) scores for our independent variables of interest (Busenbark, Lange, \& Certo, 2017; Frank, 2000; Hubbard, Christensen, \& Graffin, 2017; Oliver, Krause, Busenbark, \& Kalm, 2018), using the konfound command in Stata. The impact thresholds of the (hypothetical) omitted variables were consistently greater than the impact of variables included in the models, providing some evidence that omitted variables are not a concern in our analyses.

\section{1 | Supplemental analyses}

Our theoretical argument would imply that board-friendship ties should partially mediate the relationship between competitive uncertainty and firm performance. We conducted a separate mediation analysis using the product of coefficients method with Sobel-Goodman standard errors 
(MacKinnon et al., 2002), which confirmed that board-friendship ties to competitors is a statistically significant, partial mediator of the relationship between competitive uncertainty and ROA $(p<0.001)$.

We conducted supplemental analysis of the survey data to corroborate our theoretical argument for the performance effects of board-friendship ties. Our argument suggested that board-friendship ties to competitors' CEOs would enable a focal firm to coordinate with competitors to maintain relatively high prices and otherwise favorable contract terms with buyers, and to negotiate favorable terms with suppliers. The survey asked CEOs and directors at current or potential buyers of a focal firm, "[over the past twelve months] To what extent has [the focal firm] seemed to be acting in concert with competitors, with respect to (1) price (2) production?" "To what extent has [the focal firm] been able to keep prices higher than might be expected, given economic conditions?" "To what extent is it difficult to negotiate favorable terms with [the focal firm]?" "To what extent has [the focal firm] been able to keep its terms with [buyers in respondent's industry], with respect to price or value-added services, more favorable than might be expected, given economic conditions?" The survey included a parallel set of questions for CEOs of current or potential supplier firms. There was at least one response from the CEO of a buyer or supplier firm in each year of the study period for $69 \%$ of firms in the sample frame ( $N=351$ firms; 2,106 firm years). Confirmatory factor analysis (CFA) showed that responses to the survey items loaded on one factor as expected, with good interitem reliability $(\alpha=0.91)$. There was also high inter-rater reliability for cases with multiple respondents (Weighted Kappa $=0.86$ ).

Further analysis indicated that the factor score for this measure mediated the hypothesized effect of board-friendship ties to CEOs of competitors on firm performance in fixed-effects models of industry-adjusted ROA, ROE, and Tobin's q $(p<0.001)$. These models included the full set of control variables in Table $6 .{ }^{11}$

Our theoretical argument also suggested that board-friendship ties can be a source of competitive advantage over firms that lack such ties. To corroborate our argument, we surveyed a random sample of 300 directors from firms with at least one board-friendship tie who participated in the study. The response rate was $45 \%(N=136)$. The firms at which these directors served were not significantly different from the firms of nonrespondents with respect to the level of competitive uncertainty and measures of firm performance. We asked the directors to what extent they would agree that firms can derive a competitive advantage from having an outside director on the board who is a friend of a competitor's CEO [5-point Likert-type scale: strongly disagree...disagree...neither agree nor disagree...agree...strongly agree]. One hundred and thirty-two directors agreed or strongly agreed with this statement (97\%).

Moreover, this survey also included a series of questions about the specific forms of competitive advantage cited in our argument: "[Board-friendship ties] can facilitate coordinated attacks by connected firms against their common competitors" [5-point Likert-type scale: strongly disagree...disagree...neither agree nor disagree....agree...strongly agree]; "[Board-friendship ties] can help connected firms defend their positions against the strategic moves of their common competitors" [5-point Likert-type scale]; "A firm may avoid taking actions that would harm a competitor [to which they are connected by a board-friendship tie], but give less consideration to the adverse effect of their actions on other firms [to which they lack ties]" [5-point Likert-type scale]. Ninety-six percent of responding directors agreed or strongly agreed with the first two questions, and $94 \%$ agreed or strongly agreed with the third

\footnotetext{
${ }^{11}$ As discussed above, while our hypotheses focus on board-friendship ties that result from appointments to the focal firm's board (i.e., since these ties are more under the focal firm's control), our theory would also imply that the focal firm has the potential to realize coordination benefits when the focal CEO's friends serve on the boards of competitor firms. In fact, as shown in Table 6, there is a strong, positive relationship between the number of friends of the focal CEO who serve on the boards of competitors and subsequent firm performance.
} 
question. Overall, this survey data provides supplemental evidence suggesting that directors tend to perceive that board-friendship ties can provide a source of competitive advantage over firms that lack such ties, and it corroborates the specific mechanisms described in our theoretical argument. ${ }^{12}$

Our theoretical argument suggested that an outside director who is a friend of a rival CEO has both intrinsic and extrinsic motives not to benefit a rival at the focal CEO's expense. We cited evidence that directors who are appointed under the CEO's influence tend to feel socially obligated to return the favor by supporting the CEO's leadership in subsequent interaction (Boeker, 1992; Wade et al., 1990; Westphal, 1999; Westphal \& Bednar, 2005). We also cited evidence that directors who violate normative expectations on a particular board tend to experience social distancing from fellow directors, not only on that board, but also on other boards where they serve as director, and they are much less likely to receive future board appointments (Westphal \& Khanna, 2003; Westphal \& Stern, 2007). As described in the Appendix, moreover, we collected survey evidence that further corroborates our argument. Empirical evidence that firms tend to reconstitute broken board-friendship ties, and evidence regarding the strong performance effects of these ties, provide further support for our theory.

\section{I DISCUSSION}

Our theory and supportive findings challenge the widespread assumption that board ties no longer help firms reduce competition (Buch-Hansen, 2014; Mizruchi, 1996). Our first set of results show that the level of competitive uncertainty faced by a firm is significantly and positively related to the formation of friendship ties between a firm's outside directors and rivals' CEOs. Additional results suggest that firms were more likely to reconstitute broken board-friendship ties to the extent that they face relatively high levels of competitive uncertainty. These findings are consistent with our theoretical expectation that firms seek to manage competitive uncertainty by creating and maintaining board-friendship ties to rivals. Our second set of results addressed how firms form and maintain board-friendship ties. In particular, we found considerable evidence that executive search firms mediated the formation and maintenance of these ties. A headhunter's solicitation of director candidates from a competitor's CEO mediated the relationship between competitive uncertainty and the formation of board-friendship ties to competitors, and such solicitation also mediated the effect of competitive uncertainty on the reconstitution of broken ties.

Additional results provided evidence that board-friendship ties to rivals are associated with higher subsequent firm performance. In particular, an additional board-friendship tie to competitors improved a firm's net income by approximately $\$ 134$ million on average. Supplemental evidence provided further support for our theoretical argument regarding the mechanisms by which board-friendship ties to rivals increase firm performance. In particular, analysis of our survey data corroborated our theoretical argument that board-friendship ties facilitate interfirm coordination that enables firms to reduce competition on price and other contract terms. Survey data also corroborated our argument that board-friendship ties can provide a source of competitive advantage over firms that lack these ties, including supplemental evidence for the specific mechanisms of competitive advantage described in our theory. Taken together, our findings provided strong support for our theoretical expectations about the antecedents, maintenance, and performance consequences of board-friendship ties to competitors.

\footnotetext{
${ }^{12}$ Our interviews also suggested specific ways in which firms that are connected by board-friendship ties can achieve a competitive advantage over firms that lack these ties, and these are reflected in our theoretical argument. For example, a number of directors whom we interviewed mentioned that connected firms may jointly launch new products, advertising campaigns, or promotions that exploit weaknesses in a competitor's position, or initiate such moves when a competitor is vulnerable (e.g., during a period of financial stress, leadership change, brand repositioning, or other strategic changes).
} 
This study makes multiple important contributions to the literature on boards of directors and corporate governance. Although board interlock ties have the potential to reduce competition (Buch-Hansen, 2014; Mizruchi, 1996), such ties have become impractical as a means of managing competitive uncertainty. As discussed above, board interlock ties to competitors can violate antitrust laws, and widespread concerns about "over-boarded" executives have made it more difficult to maintain ties in which the CEO of one firm serves on another firm's board (Buch-Hansen, 2014; Harris \& Shimizu, 2004). As a result, board interlock ties between competitors are uncommon, and rarely reconstituted when broken, leading to the widespread assumption among scholars and regulators that board ties no longer help firms reduce competition (Mizruchi, 2013). Our study represents a significant challenge to this assumption. Our theory and supportive findings reveal how firms have been able to circumvent the regulatory and other constraints on board ties by appointing the friends of rival CEOs to their boards. Our theoretical argument explains the specific mechanisms that underlie the formation and maintenance of board-friendship ties, and explains how these ties may enhance firm performance by facilitating interfirm coordination that reduces rivalry. By extension, our study contributes to the corporate governance and strategic management literatures by explaining how corporate directors may facilitate interfirm collusion.

Our theory and findings regarding the role of search firms in brokering the formation and maintenance of board-friendship ties make additional important contributions to the corporate governance literature. There is very little systematic research on how consultants influence the various processes and practices of corporate governance, including director selection. There is also little if any systematic inquiry into how consultants may dampen competition or help firms circumvent regulation. In explaining how search firms broker board-friendship ties by identifying director candidates who are friends of competitors' CEOs, and then revealing how board-friendship ties may enable interfirm coordination that reduces competition, our study reveals how consultants mediate director selection in ways that circumvent regulation of board ties and may facilitate interfirm collusion.

At the same time, our study makes a broader contribution to the social network literature. Our findings suggest that search firms broker social network ties that would be considered illicit or illegitimate by some corporate stakeholders, including customers. The role of third parties in brokering illicit or illegitimate ties has been long been recognized as an important lacuna in the social network literature (Bonacich, 1973); to date, very little research has revealed such roles for third-party actors in business organizations.

Moreover, in light of prior research on the rarity of board interlock ties between competitors, our study suggests a kind of decoupling between appearances and reality with respect to social connections between the leaders of competing firms. While the rarity of board interlocks between competitors is taken to indicate the absence of communication between competitors' CEOs (Mizruchi, 1996, 2013), the absence of interlock ties often belies the presence of board-friendship ties. Moreover, search consultants exacerbate the decoupling; while consultants are known to enhance the legitimacy of executive search processes, in part by providing an ostensibly independent perspective on search criteria and potential candidates (Khurana, 2002), our study suggests that they ironically broker social ties between leaders that would be viewed as illegitimate by some firm stakeholders. In this way, search consultants facilitate decoupling, not only between appearances and reality in director selection, but also between the apparent functioning of corporate directors and their actual role in strategic management.

Our theory described the subtle and delicate communication process by which headhunters broker board-friendship ties. We described how headhunters, in speaking with the CEO of a competitor about possible board candidates, can discretely signal the purpose of the appointment. We drew from psycholinguistic theory in characterizing these communications as a kind of "off-record indirect speech" in 
which the headhunter solicits information and cooperation of a potentially illicit nature, without overtly describing the desired behavior (e.g., the exchange of strategic information) (Lee \& Pinker, 2010, p. 785). Such communication is thought to maintain the "plausible deniability" of both parties (Pinker et al., 2008, p. 834). Our study suggests that there is promise in drawing from linguistic theory to explain the role of search consultants and other information brokers in business organizations. Although our findings indicate that headhunters were often successful in soliciting board candidates who form or reconstitute board-friendship ties, the solicitation of director candidates from a competitor's CEO does not always yield viable candidates. There would be value in further qualitative and survey research that examines the specific characteristics of communications by headhunters that are relatively successful or unsuccessful in eliciting sensitive information about board candidates.

Our study has limitations, which also suggest opportunities for future research. While our supplemental survey data from corporate directors and from CEOs and directors of buyer and supplier firms provided some indirect, corroborating evidence that board-friendship ties may enhance profitability by facilitating coordination between competitors, there would clearly be value in future research that provides behavioral evidence that such ties promote cooperation that reduces the likelihood of destructive competition. For example, there would be value in studies that examine whether board-friendship ties to competitors are associated with less aggressive price competition, and a lower incidence of bidding wars for supplies. There would also be value in research that examines whether firms connected by board-friendship ties are more likely to launch strategic moves jointly against a common competitor that exploit weaknesses in the competitor's position, or to initiate such moves when the competitor is vulnerable (e.g., jointly launching new products, advertising campaigns, promotions, or other moves when the competitor is undergoing financial stress, change in leadership, or brand repositioning).

Future research could also examine how the personal and social characteristics of CEOs and directors influence board-friendship ties, or moderate their effects on strategy and performance. Given the acute lack of diversity among CEOs of public U.S. companies, one might expect a particular lack of diversity among directors who form board-friendship ties. In fact, while women and minorities now occupy over $15 \%$ of corporate board seats at large U.S. firms, less than $5 \%$ of the directors in our sample who form board-friendship ties to competitors were women or racial minorities. As more women and minorities come to occupy CEO positions over time, the diversity of directors who form boardfriendship ties may gradually increase, though the search costs associated with forming and reconstituting these ties may increase as well. Moreover, board-friendship ties may become even more valuable to firms as the diversity of business leadership increases, as demographic differences can otherwise reduce trust and impede cooperation (Turner, Hewstone, Voci, \& Vonofakou, 2008).

While the present study focuses on board-friendship ties to rivals, future studies can explore how board-friendship ties to other firms may influence corporate strategy and performance. For example, our analyses indicated that board-friendship ties to CEOs of firms in buyer and supplier industries are significantly and positively associated with subsequent firm performance. Perhaps such ties enable or strengthen partnerships with buyer and supplier firms in ways that benefit the focal firm and their partners. ${ }^{13}$ Board-friendship ties to buyer and supplier firms in other markets may also facilitate successful entry into new product or geographic markets. Extending the present

\footnotetext{
${ }^{13}$ Results for our control variables indicated that firms tend to form more board-friendship ties when they lack formal ties to competitors (e.g., joint ventures). Such formal ties may reduce the need for board-friendship ties, much as tacit collusion can reduce the need for board-friendship ties at very high levels of industry concentration (our discussion of industry concentration suggested that while board-friendship ties can be effective when competitive uncertainty is low, for example, when a small number of firms dominate an industry, firms are less motivated to incur the cost of building such ties because tacit collusion can also be effective). Future studies could examine whether board-friendship ties have stronger effects on strategic decisions to the extent that firms lack formal connections to competitors.
} 
study to explore other strategic implications of board-friendship ties seems to be a promising direction for future research.

\section{REFERENCES}

AESC. 2011. The association of executive search and leadership consultants outlook report. Retrieved from https://www.aesc.org/ insights/thought-leadership/aesc-insights/2011-aesc-outlook-report

Ang, S. H. (2008). Competitive intensity and collaboration: Impact on firm growth across technological environments. Strategic Management Journal, 29, 1057-1075.

Awaya, Y., \& Krishna, V. (2014). On tacit versus explicit collusion. Working Paper, Pennsylvania State University.

Baker, W. E., \& Faulkner, R. R. (1993). The social organization of conspiracy: Illegal networks in the heavy electrical equipment industry. American Sociological Review, 58, 837-860.

Bidwell, M. (2011). Paying more to get less: The effects of external hiring versus internal mobility. Administrative Science Quarterly, $56,369-407$.

Boeker, W. (1992). Power and managerial dismissal: Scapegoating at the top. Administrative Science Quarterly, 37, 400-421.

Bonacich, E. (1973). Theory of middleman minorities. American Sociological Review, 38, 583-594.

Bonet, R., Cappelli, P., \& Hamori, M. (2013). Labor market intermediaries and the new paradigm for human resources. Academy of Management Annals, 7, 341-392.

Brass, D. J. (1984). Being in the right place: A structural analysis of individual influence in an organization. Administrative Science Quarterly, 29, 518-539.

Bruynseels, L., \& Cardinaels, E. (2014). The audit committee: Management watchdog or personal friend of the CEO? Accounting Review, 89, 113-145.

Buch-Hansen, H. (2014). Interlocking directorates and collusion: An empirical analysis. International Sociology, 29, $249-267$.

Burt, R. S. (1982). Toward a structural theory of action: Network models of social structure, perception, and action. New York, NY: Academic Press.

Burt, R. S. (1983). Corporate profits and cooptation: Networks of market constraints and directorate ties in the American economy. New York, NY: Academic Press.

Busenbark, J. R., Lange, D., \& Certo, S. T. (2017). Foreshadowing as impression management: Illuminating the path for security analysts. Strategic Management Journal, 38, 2486-2507.

Certo, S. T., Busenbark, J. R., Woo, H. S., \& Semadeni, M. (2016). Sample selection bias and Heckman models in strategic management research. Strategic Management Journal, 37, 2639-2657.

Chatterjee, A., \& Hambrick, D. C. (2007). It's all about me: Narcissistic chief executive officers and their effects on company strategy and performance. Administrative Science Quarterly, 52, 351-386.

Chen, G., \& Hambrick, D. C. (2012). CEO replacement in turnaround situations: Executive (mis)fit and its performance implications. Organization Science, 23, 225-243.

Cook, K. S., Emerson, R. M., Gillmore, M. R., \& Yamagishi, T. (1983). The distribution of power in exchange networks: Theory and experimental results. American Journal of Sociology, 89, 275-305.

Cool, K., \& Henderson, J. (1998). Power and firm profitability in supply chains: French manufacturing industry in 1993. Strategic Management Journal, 19, 909-926.

Crane, D. A. (2011). The institutional structure of antitrust enforcement. Oxford, NY: Oxford University Press.

Crossland, C., \& Chen, G. (2013). Executive accountability around the world: Sources of cross-national variation in firm performance-CEO dismissal sensitivity. Strategic Organization, 11, 78-109.

D'Aveni, R. A. (1994). Hypercompetition: Managing the dynamics of strategic maneuvering. New York, NY: The Free Press.

Emerson, R. M. (1962). Power-dependence relations. American Sociological Review, 27, 31-41.

Finkelstein, S., \& Hambrick, D. C. (1990). Top-management-team tenure and organizational outcomes: The moderating role of managerial discretion. Administrative Science Quarterly, 35, 484-503.

Finkelstein, S., Hambrick, D. C., \& Cannella, A. A. (2009). Strategic leadership: Theory and research on executives, top management teams, and boards. New York, NY: Oxford University Press.

Fleiss, J. L. (1981). Balanced incomplete block designs for inter-rater reliability studies. Applied Psychological Measurement, 5, 105-112.

Fowler, F. J. (2014). Survey research methods (5th ed.). Thousand Oaks, CA: Sage.

Frank, K. A. (2000). Impact of a confounding variable on a regression coefficient. Sociological Methods \& Research, 29, $147-194$.

Gibbons, J. D., \& Chakraborti, S. (2011). Nonparametric statistical inference (5th ed.). Boca Raton, FL: Taylor \& Francis.

Greer, T. V., Chuchinprakarn, N., \& Seshadri, S. (2000). Likelihood of participating in mail survey research: Business respondents' perspectives. Industrial Marketing Management, 29, 97-109.

Grice, J. W., \& Harris, R. J. (1998). A comparison of regression and loading weights for the computation of factor scores. Multivariate Behavioral Research, 33, 221-247.

Harrington, J. E. (2005). Optimal cartel pricing in the presence of an antitrust authority. International Economic Review, 46, $145-169$. 
Harris, I. C., \& Shimizu, K. (2004). Too busy to serve? An examination of the influence of overboarded directors. Journal of Management Studies, 41, 775-798.

Hays, R. B. (1985). A longitudinal study of friendship development. Journal of Personality and Social Psychology, 48, 909-924.

Hillman, A. J., \& Dalziel, T. (2003). Boards of directors and firm performance: Integrating agency and resource dependence perspectives. Academy of Management Review, 28, 383-396.

Hillman, A. J., Withers, M. C., \& Collins, B. J. (2009). Resource dependence theory: A review. Journal of Management, 35, 1404-1427.

Holsti, O. R. (1968). Content analysis. In G. Lindzey \& E. Aronson (Eds.), The handbook of social psychology (Vol. 2, pp. 596-692). Reading, MA: Addison-Wesley.

Hubbard, T. D., Christensen, D. M., \& Graffin, S. D. (2017). Higher highs and lower lows: The role of corporate social responsibility in CEO dismissal. Strategic Management Journal, 38, 2255-2265.

Ibarra, H., \& Andrews, S. B. (1993). Power, social influence, and sense making: Effects of network centrality and proximity on employee perceptions. Administrative Science Quarterly, 38, 277-303.

Ingram, P., \& Roberts, P. W. (2000). Friendships among competitors in the Sydney hotel industry. American Journal of Sociology, 106, 387-423.

Khurana, R. (2002). Searching for a corporate savior: The irrational quest for charismatic CEOs. Princeton, NJ: Princeton University Press.

Kilduff, M., \& Tsai, W. (2003). Social networks and organizations. London, England; Thousand Oaks, CA: SAGE.

Krackhardt, D. (1992). The strength of strong ties: The importance of philos in organizations. In N. Nohria \& R. G. Eccles (Eds.), Networks and organizations: Structure, form, and action (pp. 216-239). Boston, MA: Harvard Business School Press.

Krackhardt, D., \& Kilduff, M. (1999). Whether close or far: Social distance effects on perceived balance in friendship networks. Journal of Personality and Social Psychology, 76, 770-782.

Krackhardt, D., \& Porter, L. W. (1985). When friends leave: A structural analysis of the relationship between turnover and stayers' attitudes. Administrative Science Quarterly, 30, 242-261.

Lee, J. J., \& Pinker, S. (2010). Rationales for indirect speech: The theory of the strategic speaker. Psychological Review, 117, 785-807.

Lorsch, J. W., \& MacIver, E. (1989). Pawns or potentates: The reality of America's corporate boards. Boston, MA: Harvard Business School Press.

MacKinnon, D. P., Lockwood, C. M., Hoffman, J. M., West, S. G., \& Sheets, V. (2002). A comparison of methods to test mediation and other intervening variable effects. Psychological Methods, 7, 83-104.

MacKinnon, D. P., Lockwood, C. M., \& Williams, J. (2004). Confidence limits for the indirect effect: Distribution of the product and resampling methods. Multivariate Behavioral Research, 39, 99-128.

Mizruchi, M. S. (1996). What do interlocks do? An analysis, critique, and assessment of research on interlocking directorates. Annual Review of Sociology, 22, 271-298.

Mizruchi, M. S. (2013). The fracturing of the American corporate elite. Cambridge, MA: Harvard University Press.

Monge, P. R., \& Contractor, N. S. (2003). Theories of communication networks. Oxford, NY: Oxford University Press.

Oliver, A. G., Krause, R., Busenbark, J. R., \& Kalm, M. (2018). BS in the boardroom: Benevolent sexism and board chair orientations. Strategic Management Journal, 39, 113-130.

Page-Gould, E., Mendoza-Denton, R., \& Tropp, L. R. (2008). With a little help from my cross-group friend: Reducing anxiety in intergroup contexts through cross-group friendship. Journal of Personality and Social Psychology, 95, 1080-1094.

Palmer, D. (1983). Broken ties: Interlocking directorates and intercorporate coordination. Administrative Science Quarterly, 28, 40-55.

Palmer, D., Singh, J. V., \& Friedland, R. (1986). The ties that bind: Organizational and class bases of stability in a corporate interlock network. American Sociological Review, 51, 781-796.

Palmer, D. A., Barber, B. M., Zhou, X., \& Soysal, Y. (1995). The friendly and predatory acquisition of large U.S. corporations in the 1960s: The other contested terrain. American Sociological Review, 60, 469-499.

Park, S. H., \& Westphal, J. D. (2013). Social discrimination in the corporate elite: How status affects the propensity for minority CEOs to receive blame for low firm performance. Administrative Science Quarterly, 58, 542-586.

Pfeffer, J., \& Salancik, G. R. (1978). The external control of organizations: A resource dependence approach. New York, NY: Harper and Row.

Pinker, S., Nowak, M. A., \& Lee, J. J. (2008). The logic of indirect speech. Proceedings of the National Academy of Sciences of the United States of America, 105, 833-838.

Porter, M. E. (1980). Competitive strategy: Techniques for analyzing industries and competitors. New York, NY: Free Press.

Porter, M. E. (1998). Clusters and the new economics of competition. Harvard Business Review, 76, 77-90.

Porter, R. (2005). Detecting collusion. Review of Industrial Organization, 26, 147-167.

Preacher, K. J., \& Hayes, A. F. (2008). Asymptotic and resampling strategies for assessing and comparing indirect effects in multiple mediator models. Behavior Research Methods, 40, 879-891.

Segal, M. W. (1979). Varieties of interpersonal attraction and their interrelationships in natural groups. Social Psychology Quarterly, 42, 253-261. 
Soda, G., \& Usai, A. (1999). The dark side of dense networks. In A. Grandori (Ed.), Interfirm networks: Organization and industrial competitiveness (pp. 276-302). London, England: Routledge.

Stigler, G. J. (1964). A theory of oligopoly. Journal of Political Economy, 72, 44-61.

Sugaya, T., \& Takahashi, S. (2013). Coordination failure in repeated games with private monitoring. Journal of Economic Theory, 148, 1891-1928.

Sutcliffe, K. M., \& Zaheer, A. (1998). Uncertainty in the transaction environment: An empirical test. Strategic Management Journal, 19, 1-23.

Swart, H., Hewstone, M., Christ, O., \& Voci, A. (2011). Affective mediators of intergroup contact: A three-wave longitudinal study in South Africa. Journal of Personality and Social Psychology, 101, 1221-1238.

Terza, J. V. (1998). Estimating count data models with endogenous switching: Sample selection and endogenous treatment effects. Journal of Econometrics, 84, 129-154.

Turner, R. N., Hewstone, M., Voci, A., \& Vonofakou, C. (2008). A test of the extended intergroup contact hypothesis: The mediating role of intergroup anxiety, perceived ingroup and outgroup norms, and inclusion of the outgroup in the self. Journal of Personality and Social Psychology, 95, 843-860.

Utton, M. A. (2011). Cartels and economic collusion: The persistence of corporate conspiracies. Cheltenham, England; Northampton, MA: Edward Elgar.

Uzzi, B. (1997). Social structure and competition in interfirm networks: The paradox of embeddedness. Administrative Science Quarterly, 42, 35-67.

Wade, J., O'Reilly, C. A., \& Chandratat, I. (1990). Golden parachutes: CEOs and the exercise of social influence. Administrative Science Quarterly, 35, 587-603.

Weber, R. P. (1985). Basic content analysis. Beverly Hills, CA: Sage.

Westphal, J. D. (1999). Collaboration in the boardroom: Behavioral and performance consequences of CEO-board social ties. Academy of Management Journal, 42, 7-24.

Westphal, J. D., \& Bednar, M. K. (2005). Pluralistic ignorance in corporate boards and firms' strategic persistence in response to low firm performance. Administrative Science Quarterly, 50, 262-298.

Westphal, J. D., Boivie, S., \& Chng, D. H. M. (2006). The strategic impetus for social network ties: Reconstituting broken CEO friendship ties. Strategic Management Journal, 27, 425-445.

Westphal, J. D., \& Deephouse, D. L. (2011). Avoiding bad press: Interpersonal influence in relations between CEOs and journalists and the consequences for press reporting about firms and their leadership. Organization Science, 22, 1061-1086.

Westphal, J. D., \& Khanna, P. (2003). Keeping directors in line: Social distancing as a control mechanism in the corporate elite. Administrative Science Quarterly, 48, 361-398.

Westphal, J. D., \& Stern, I. (2007). Flattery will get you everywhere (especially if you are a male caucasian): How ingratiation, boardroom behavior, and demographic minority status affect additional board appointments at US companies. Academy of Management Journal, 50, 267-288.

Westphal, J. D., \& Zajac, E. J. (2013). A behavioral theory of corporate governance: Explicating the mechanisms of socially situated and socially constituted agency. Academy of Management Annals, 7, 607-661.

Wiseman, R. M. (2009). On the use and misuse of ratios in strategic management research. In D. D. Bergh \& D. J. Ketchen (Eds.), Research methodology in strategy and management (Vol. 5, pp. 75-110). Bingley, U.K.: Emerald Group.

Wooldridge, J. M. (2010). Econometric analysis of cross section and panel data. Cambridge, MA: The MIT Press.

Zajac, E. J., \& Bazerman, M. H. (1991). Blind spots in industry and competitor analysis: Implications of interfirm (mis)perceptions for strategic decisions. Academy of Management Review, 16, 37-56.

Zeng, Z., \& Xie, Y. (2008). A preference-opportunity-choice framework with applications to intergroup friendship. American Journal of Sociology, 114, 615-648.

How to cite this article: Westphal JD, Zhu DH. Under the radar: How firms manage competitive uncertainty by appointing friends of other chief executive officers to their boards*. Strat. Mgmt. J. 2019;40:79-107. https://doi.org/10.1002/smj.2966 


\section{A. APPENDIX}

\section{A.1. MEASURES TO INCREASE THE SURVEY RESPONSE RATE}

To ensure the quality of the survey and maximize participation rates, we conducted a pretest of the questionnaire during in-depth interviews with 26 current or former directors from firms in the population. We used input from the interviews to improve the layout and instructions of the survey, and to refine the wording of specific questions (Fowler, 2014). We also obtained the endorsement of a well-known corporate leader and a major management consulting firm with an excellent reputation in the area of corporate governance. The invitation to participate described the survey as part of an established program of research on firm leadership and governance involving faculty members of multiple leading business schools, and highlighted that thousands of managers and directors had participated in previous surveys (Fowler, 2014; Greer, Chuchinprakarn, \& Seshadri, 2000).

\section{A.2. SURVEY MEASURE OF COMPETITIVE UNCERTAINTY}

1. How predictable would the actions of competitors be, in the absence of measures to reduce the uncertainty? [5-point scale: not at all...somewhat...very predictable].

2. How predictable would competition with other firms be, without strategies to reduce the uncertainty? [5-point scale: not at all...somewhat...very predictable].

3. To what extent would it be difficult to anticipate the actions of competitors, without strategies to reduce the uncertainty? [5-point scale: not at all...somewhat...very much so].

4. To what extent would it be difficult to infer the intentions or plans of competitors from their actions alone? [5-point scale: not at all...somewhat...very much so].

5. To what extent would it be difficult to predict competition with other firms, in the absence of measures to reduce the uncertainty? [5-point scale: not at all...somewhat...very much so].

6. [At the focal firm] how much uncertainty would you face in regards to the actions of competitors, in the absence of strategies to reduce the uncertainty? [5-point scale: very little uncertainty... some uncertainty.... a great deal of uncertainty].

\section{A.3. ADDITIONAL INFORMATION ON MEASURES}

\section{A.3.1. Control for Resource Dependence}

Westphal et al.'s (2006) measure of organizational dependence on resource providers is founded on Emerson's (1962) theory of dependence power (also Cook, Emerson, Gillmore, \& Yamagishi, 1983), which suggests that the dependence of actor A on resource provider B increases as (a) the value of the resource to A increases and (b) alternative providers of the resource decrease. To gauge alternative providers, Westphal et al.'s (2006) survey measure prompts respondents to (a) list the firm's inputs and distribution channels, and (b) for each input/channel, list their primary partners (up to 5 per input/channel). We then calculated the four-firm concentration ratio of each partner's industry (Westphal et al., 2006); a higher concentration ratio indicates fewer alternatives for a particular input or channel (Burt, 1983; Palmer et al., 1995; Porter, 1998). To assess the value of resources provided by exchange partners, Westphal et al. (2006) developed a four-item scale based 
on Cool and Henderson's (1998) measure of dependence power in supply chains. Specific questions prompt respondents to assess the impact of each input (or services provided by buyers in a particular channel) on differentiation of the focal firm's products and/or services (e.g., "The impact of this input on your product or service differentiation is [5-point scale: weak...strong]"; "To what extent are the services provided by partners in this channel important to differentiating your products or services?" [5-point scale: not very important...extremely important]; "This input has a significant impact on the differentiation of our [products/services]" [5-point scale: strongly disagree... strongly agree]; "The services provided by partners in this channel have a significant impact on the differentiation of our [products/services]" [5-point scale: strongly disagree...strongly agree]). Westphal et al. (2006) provided evidence for the inter-rater reliability and convergent validity of items in the scale. To further assess reliability, we compared the responses of directors at the same firm. Weighted Kappa coefficients for the survey items ranged from 0.81 to 0.92 , indicating a high level of inter-rater agreement (Fleiss, 1981). Moreover, CFA indicated that all four items loaded on a single factor with acceptable interitem reliability. We estimated factor scores using the regression method. Following Westphal et al. (2006), dependence on resource providers represents the interaction between these two variables (Concentration of buyer/supplier industry $\times$ Perceived value of resources provided by the exchange partner). Emerson and Cook's conception of dependence power would suggest that resource dependence on a supplier or buyer is a function of the interaction between these two variables. In other words, dependence on another organization increases to the extent that there are few alternative providers of the resource (as indicated by concentration of the buyer/supplier industry) and the resource is relatively important strategically to the focal firm. The hypothesized results were unchanged in models that included (a) only concentration of buyer/ supplier industries, (b) only the perceived value of resources provided by exchange partners, or (c) both main effects, without the interaction term.

\section{A.4. SAMPLE SELECTION MODELS}

We estimated a Heckman poisson model (Terza, 1998) in which the selection equation estimates participation in the study among the larger sample frame of 900 firms (as noted above, firms in this sample frame are representative of firms in the larger population of large and medium-sized public U.S. firms on each of the archival variables in our study). As an exclusion restriction, we used the number of directors on the board nominating committee who had participated in a prior survey by the first author. This variable was a strong predictor of participation in the current study, but was not significantly related to board-friendship ties. The Wald test of independent equations (rho $=0$ ) was not statistically significant $(p=0.346)$, providing some indication that sample selection bias is not affecting our results (Wooldridge, 2010). Moreover, as noted above, none of the independent variables from the main equation were significant in the selection equation (the selection equation did not include the survey measure of competitive uncertainty, which is only available for study participants; as noted above, however, this measure is strongly correlated with the archival measures of competitive uncertainty, and the latter are not significant predictors in the selection equation). As discussed above, the independent variable of interest must be a significant predictor in the selection equation for sample selection bias to exist (Certo et al., 2016). In any event, the hypothesized effect of competitive uncertainty was strongly significant in this model.

We also estimated a Heckman probit model in which the selection equation estimates the likelihood of a broken tie among the full sample of board-friendship ties. As an exclusion restriction, we 
used a dichotomous variable that indicates whether the CEO of Alter (the tied to firm) was over age 65. This variable was strongly related to the likelihood of a broken tie, but unrelated to the likelihood of reconstitution. Again, the likelihood ratio test of independent equations (rho $=0$ ) was not statistically significant $(p=0.461)$, and none of the independent variables from the main equation were significant in the selection equation, providing some indication that sample selection bias is not affecting our results (Certo et al., 2016; Wooldridge, 2010). In any case, the effect of competitive uncertainty remained strongly significant in the model.

\section{A.5. SUPPLEMENTAL EVIDENCE REGARDING DIRECTOR MOTIVES}

To further corroborate our argument that an outside director who is a friend of a rival CEO has motives not to benefit a rival at the focal CEO's expense, in the last iteration of the surveys, we asked responding directors whether individual members of their board, including directors who form boardfriendship ties, would suffer adverse consequences from helping a competitor at the focal firm's expense. Ninety-three percent of responding directors agreed or strongly agreed that "if [an individual director specified in the survey] were to help a competitor at [the focal firm's] expense, [he/she] would have difficulty obtaining board appointments in the future." Ninety-four percent agreed or strongly agreed that "if [an individual director specified in the survey] were to share

TABLE A1 Fixed-effects regression analysis of net income ${ }^{\mathrm{a}}$

\begin{tabular}{|c|c|}
\hline \multicolumn{2}{|l|}{ Independent variable } \\
\hline 1. Board-friendship ties to chief executive officers (CEOs) of competitors & $\begin{array}{l}283.33[.000] \\
(\mathbf{1 7 . 0 9 )}\end{array}$ \\
\hline 2. Board-friendship ties to CEOs of firms in buyer/supplier industries & $\begin{array}{l}226.10[.000] \\
(14.21)\end{array}$ \\
\hline 3. Friendship ties between CEO of focal firm and CEOs of competitors & $\begin{array}{l}142.48[.114] \\
(90.06)\end{array}$ \\
\hline 4. Friendship ties between CEO of focal firm and CEOs of firms in buyer/supplier industries & $\begin{array}{l}195.94[.024] \\
(86.53)\end{array}$ \\
\hline 5. Focal CEO's friends on boards of competitors & $\begin{array}{l}316.12[.000] \\
(32.36)\end{array}$ \\
\hline 6. Focal CEO's friends on boards of resource providers & $\begin{array}{l}6.24[.783] \\
(0.0007)\end{array}$ \\
\hline 7. Log of sales & $\begin{array}{l}630.26[.000] \\
(30.83)\end{array}$ \\
\hline 8. Debt to equity ratio & $\begin{array}{l}11.255[.031] \\
(5.20)\end{array}$ \\
\hline 9. $\mathrm{R} \& \mathrm{D}$ ratio & $\begin{array}{l}2,266.17[.030] \\
(1,044.32)\end{array}$ \\
\hline 10. Advertising ratio & $\begin{array}{l}5,256.05[.007] \\
(1953.92)\end{array}$ \\
\hline 11. Capital expenditure & $\begin{array}{l}660.69[.026] \\
(296.27)\end{array}$ \\
\hline 12. Assets & $\begin{array}{l}0.006[.000] \\
(0.0002)\end{array}$ \\
\hline Constant & $\begin{array}{l}674.03[.015] \\
(277.03)\end{array}$ \\
\hline$F$ & 126.58 \\
\hline
\end{tabular}

${ }^{\text {a }} N=3054 . p$ values are in brackets (two-tailed tests); standard errors are in parentheses. Year dummies are included. 
sensitive information with a competitor in a way that harms [the focal firm], it would have very negative consequences for [his/her] reputation"; the same percentage agreed or strongly agreed that "a director who shares sensitive information with a competitor in a way that disadvantages [the focal firm] would face negative consequences for [his/her] career." For the subsample of directors who form board-friendship ties, 97-98\% of respondents agreed or strongly agreed with these statements, with over $85 \%$ of respondents strongly agreeing with these statements.

Thus, there was near-consensus among respondents that directors, including those who form board-friendship ties, would face adverse career consequences if they were to help a competitor at the focal firm's expense. The expectation of such consequences should deter directors who form board-friendship ties from using their position to help a competitor in ways that harm the focal firm. 